\title{
Growth and Yield response of Maize (Zea mays L.) to Different Rates of NPK fertilizer and Poultry manure in the Western Highlands of Cameroon
}

\author{
FONCHA Felix ${ }^{1 *}$, WIRNKAR Lendzemo Venasius ${ }^{1}$, BAME Irene Bonsiysi ${ }^{1}$, NSUH Konje Christina ${ }^{2}$, MBONG \\ Mabu Boris ${ }^{2}$ and MBONG Grace Annih ${ }^{3}$ \\ ${ }^{1}$ Institute of Agricultural Research for Development (IRAD) Bambui, P.O Box 51 OR 80 Bamenda, Cameroon \\ ${ }^{2}$ Department of Crop Production Technology, College of Technology, University of Bamenda, P.O Box 39 Bambili, \\ Cameroon
}

${ }^{3}$ Department of Plant Biology, Faculty of Science, University of Dschang, P.O Box 67 Dschang, Cameroon

\begin{abstract}
Low soil fertility is one of the factors hindering crop production in Cameroon. This is attributed to the fact that continuous cropping is carried out without adequate external farm inputs. The adoption of an Integrated Soil Fertility Management (ISFM) technique such as the combination of organic manure and chemical fertilizers is being taken as one of the solutions to this problem. A study was conducted during the main cropping season in the experimental farm of the Institute of Agricultural Research for Development (IRAD), Bambui in the Western Highlands of Cameroon to investigate the effect of different rates of NPK fertilizer and poultry manure on the growth and yield of maize (Zea mays L.). The field was laid out in a randomized complete block design with tree replications and twelve treatments which were: no input (control), 300KgNPK/ha + OKg PM (Poultry manure) $/ \mathrm{ha}, 150 \mathrm{KgNPK} / \mathrm{ha}+\mathrm{OKg} \mathrm{PM} / \mathrm{ha}, 0 \mathrm{KgNPK} / \mathrm{ha}+2.5$ tons PM/ha, OKgNPK/ha + 5tons PM/ha, OKgNPK/ha+10tonsPM/ha,150KgNPK/ha+2.5tonsPM/ha,150KgNPK/ha+5tonsPM/ha,150KgNPK/ha+10tonsPM/ha,

$180 \mathrm{KgNPK} / \mathrm{ha}+2.5$ tonsPM/ha,180KgNPK/ha+5tons PM/ha and180KgNPK/ha + 10tons PM/ha. Each plot measured $4 \mathrm{~m} \times 5 \mathrm{~m}$. Planting was done at a spacing of $80 \mathrm{~cm} \times 50 \mathrm{~cm}$ with two seeds per station to maintain a plant population of 50,000 plants per hectare. All cultural practices were followed from planting to harvesting. The data collected were plant height, number of leaves per plant, stem girth, leaf area, Ear length, Ear girth, number of grain rows per ear, number of grains per ear, weight of 1000 grains, and grain yield. The analysis of variance (ANOVA) was run to find the differences between the various parameters and the LSD Fisher's multiple range test was executed to compare the different treatments. The results of the study showed that application of $0 \mathrm{kgNPK} / \mathrm{ha}+10 \mathrm{tons} P M / \mathrm{ha}$ and $0 \mathrm{kgNPK} / \mathrm{ha}+5$ tons $P M / \mathrm{ha}$ significantly $(P<0.05)$ increased the growth and yield of maize as compared to the other treatments. The application rate of $300 \mathrm{kgNPK} / \mathrm{ha}+0 \mathrm{~kg} P M / \mathrm{ha}$ also enhanced the growth and yield of maize. Besides that, the treatment $150 \mathrm{KgNPK} / \mathrm{ha}+2.5$ tons PM/ha also gave higher yields. This later treatment may be recommended to maize producers in the study area to improve maize yields since it is more economical in terms of cost of production.
\end{abstract}

Key words: Poultry manure, NPK fertilizer, Maize, Growth, Yield.

\section{INTRODUCTION}

Maize (Zea mays L.) is an essential cereal crop grown in the world for human food, feed, industrial uses and bio-energy [1], [2]. In the less developed world such as the Sub-Saharan Africa (SSA), maize is mostly grown for food by small scale farmers under rain-fed conditions and low production inputs like fertilizers and phytosanitary products [1], [3]. About $69.6 \%$ of the countries in the world with the highest per capita consumption of maize are found in SSA [1], [3]. Maize production has greatly contributed to food security and employment in Cameroon. It is the most produced and consumed cereal crop with over 700,000 farm families involved in its cultivation [1], [5]. In Cameroon, maize serves in a variety of traditional dishes (con fufu, corky corn, corn chaff...) as well as drinks (corn beer, scha, pap...).

Maize production in the Western highlands of Cameroon is constrained by a number of factors like diseases, insect pests, soil acidity, environmental degradation weed infestations and low soil fertility [1], [6]. The adoption of Integrated Soil Fertility Management (ISFM) technique such as the combination of organic manure and mineral fertilizers is one of solutions to 
this problem. The present study was carried out to investigate the effect of different rates of NPK fertilizer and poultry manure on growth and yield of maize (Zea mays L.).

\section{MATERIALS AND METHODS}

\subsection{Study Site}

The study was performed at the experimental field of the Institute of Agricultural Research for Development (IRAD) Bambui, at the Nfonta Sub-station of the Western highlands of Cameroon. Nfonta is a low land situated at the altitude of $1250 \mathrm{~m}$ above sea level area with Savanna vegetation. This area is characterized by an average rainfall of 2230mm/annum uniformly distributed from mid-march to mid-November with the highest peak of 380mm occurring in the month of July and August. The temperatures are slightly cold with an average minimum and maximum of $18-28^{\circ} \mathrm{C}$ respectively. The average humidity is $75 \%$ and $52 \%$ in the rainy and dry season respectively. The soil is well drained and good for maize production.

\subsection{Land Preparation}

The land was ploughed with a tractor and harrowed with hoe to pulverize the soil. Plots were then marked out in the land. Each plot size was $4 \mathrm{~m} \times 5 \mathrm{~m}$ with a distance of $50 \mathrm{~cm}$ between plots and $1 \mathrm{~m}$ separating one block (replication) from the other. The whole experimental field measured $53.5 \mathrm{~m} \times 17 \mathrm{~m}\left(909.5 \mathrm{~m}^{2}\right)$.

\subsection{Experimental Design}

The experiment was laid out in a randomized complete block design (RCBD). There were twelve treatments (Table 1) replicated three times.

Table 1: The twelve experimental treatments

\begin{tabular}{|c|c|}
\hline Treatment code & Treatment \\
\hline $\mathrm{T} 1$ & Control (no application) \\
\hline $\mathrm{T} 2$ & $300 \mathrm{Kg}$ NPK $(14-24-14) \mathrm{ha}^{-1}+0 \mathrm{Kg}$ Poultry manure $\mathrm{ha}^{-1}$ \\
\hline $\mathrm{T} 3$ & $150 \mathrm{Kg}$ NPK (14-24-14) ha ${ }^{-1}+0 \mathrm{Kg}$ Poultry manure $\mathrm{ha}^{-1}$ \\
\hline $\mathrm{T} 4$ & 0Kg NPK (14-24-14) ha ${ }^{-1}+2.5$ tons Poultry manure ha $^{-1}$ \\
\hline T5 & 0Kg NPK (14-24-14) ha $^{-1}+5$ tons Poultry manure ha ${ }^{-1}$ \\
\hline T6 & 0Kg NPK (14-24-14) ha ${ }^{-1}+10$ tons Poultry manure ha $^{-1}$ \\
\hline $\mathrm{T} 7$ & $150 \mathrm{Kg}(14-24-14) \mathrm{NPK} \mathrm{ha}^{-1}+2.5$ tons Poultry manure $\mathrm{ha}^{-1}$ \\
\hline $\mathrm{T} 8$ & $150 \mathrm{Kg}$ NPK $(14-24-14)$ ha $^{-1}+5$ tons Poultry manure ha $^{-1}$ \\
\hline T9 & $150 \mathrm{Kg}$ NPK $(14-24-14)$ ha $^{-1}+10$ tons Poultry manure ha $^{-1}$ \\
\hline $\mathrm{T} 10$ & $180 \mathrm{Kg}$ NPK $(14-24-14)$ ha $^{-1}+2.5$ tons Poultry manure ha $^{-1}$ \\
\hline T11 & $180 \mathrm{Kg}$ NPK $(14-24-14)$ ha $^{-1}+5$ tons Poultry manure ha $^{-1}$ \\
\hline $\mathrm{T} 12$ & $180 \mathrm{Kg}$ NPK (14-24-14) ha ${ }^{-1}+10$ tons Poultry manure ha $^{-1}$ \\
\hline
\end{tabular}

\subsection{Planting and Cultural Practices}

Maize seeds, CHC 201 ('KASAI'), an open-pollinated white variety obtained from the Institute of Agricultural Research for Development (IRAD) Bambui were sown on the $17^{\text {th }}$ April 2018. The NPK: 14-24-14 and poultry manure treatments were applied in the planting holes and slightly covered with some soil. Three to four seeds were sown per hole at a depth of $5 \mathrm{~cm}$ in a planting distance of $80 \mathrm{~cm}$ row to row and $50 \mathrm{~cm}$ plant to plant at the spots of fertilizer and/or poultry manure application. Immediately after germination, thinning was done (unhealthy seedlings discarded) to maintain two seedlings per stand with the aim of achieving 50,000 plants per hectare. The field was kept relatively weed free from planting to harvesting. The experimental units were manually weeded using small hoes while insects and pests were also effectively controlled every 3 weeks using EMACOT insecticide. Moulding was done uniformly in all the experimental units. Field borders were properly cleared to reduce insects and rodents pressure on the trial.

\subsection{Data Collection}

Data collection started three weeks after planting (WAP). The growth and yield parameters recorded at different stages of the crop growth cycle were: plant height, number of leaves, leaf area, stem girth, ear length, ear girth, number of grain rows per ear, number of grains per ear, 1000 grain weight and grain yield. The various parameters were taken as follows: Plant height: It was taken from ten randomly selected plants middle row plants marked in each plot. A carpenter's tape was used to measure the height from ground level to the uppermost leaf and the mean plant height calculated for each plot. Number of green leaves: Visual counting of green leaves was made from the ten marked leaves and the average calculated for each plot. Stem girth: It was 
measured from the ten marked plants using a thread and the actual length determined using a carpenter's tape. The mean girths were then calculated for each plot. Leaf area: It was determined from length $\mathrm{x}$ width method ${ }^{[1] \text {, [7] }}$ using the formula

Leaf area $=0.75$ (length $\mathrm{x}$ width), where 0.75 is a constant. Ten leaves were measured with a tailor's tape from each plot and the mean leaf area determined. Ear girth: The ear girths for ten dehusked ears from each plot were measured as described above for stem girth. Number of grain rows and number of grains per ear: These were determined from the ten marked ears from each plot and the average for each plot calculated. 1000-grain weight: One thousand grains were counted from each plot and their dry weight measured. Grain yield: The dry weights of maize grains harvested from $1 \mathrm{~m}^{2}$ in the middle rows of each plot were weighed and the yield estimated using the formula:

Grain yield $=\left\{\frac{\text { weight of maize grains from } 1 \text { square metre in } \mathrm{kg} \mathrm{x} \mathrm{10,000}}{1000}\right\}$ ton $/ \mathrm{ha}^{[1]}$.

\subsection{Statistical Analyses}

The data analyses were executed with the aid of the STATGRAPHICS Plus version 5.0 Software. The analysis of variance (ANOVA) was run to find the differences between the various parameters and the LSD Fisher's test at 95\% confidence level was used to compare the different treatments.

\section{RESULTS}

\subsection{Effects of Different Rates of NPK and Poultry Manure on Plant Height}

The information shown in Table 2 reveal that the plant height increased across the treatments for all the growth stages. The plant height ranged from $23.43 \mathrm{~cm}$ in the T4 treatment to $270.67 \mathrm{~cm}$ in the T6 treatment. The control (T1) recorded the lowest plant height at $8 \mathrm{WAP}$ and $12 \mathrm{WAP}$. At $4 \mathrm{WAP}$ there was no significant difference $(\mathrm{P}>0.05)$ in the plant height of the control treatment and T2, T3, T4 and T12 treatments. At $8 \mathrm{WAP}$, the plant height of the control treatment differed significantly $(\mathrm{P}<0.05)$ from those from T4, T5 and T6 treatments but showed no significant difference from those of the other treatments. At 12WAP, plant height in the control plot differed significantly from those of the other treatments. At 12WAP, the plant height in the T6 treatment was the highest and differed significantly from those of the rest of the treatments

Table 2: Effects of different rates of NPK and Poultry manure on Plant height $(\mathrm{cm})$

\begin{tabular}{|c|c|c|c|c|}
\hline \multirow{2}{*}{$\begin{array}{l}\text { Treatment } \\
\text { Code }\end{array}$} & \multirow[t]{2}{*}{ Treatment } & \multicolumn{3}{|c|}{ Mean \pm Standard deviation(SD) at weeks after planting } \\
\hline & & 4 & 8 & 12 \\
\hline TI & Control & $23.48 \pm 0.73^{\mathrm{ef}}$ & $60.27 \pm 2.05^{\mathrm{d}}$ & $170.00 \pm 9.64^{\mathrm{h}}$ \\
\hline $\mathrm{T} 2$ & 300kg NPK/ha + 0kg PM/ha & $23.43 \pm 0.64^{\mathrm{ef}}$ & $68.67 \pm 19.26^{\text {bcd }}$ & $245.00 \pm 5.29^{\mathrm{bc}}$ \\
\hline $\mathrm{T} 3$ & 150kg NPK/ha + 0kg PM/ha & $24.09 \pm 0.28^{\mathrm{ef}}$ & $72.87 \pm 13.30^{\text {bcd }}$ & $209.67 \pm 8.02^{\text {ef }}$ \\
\hline $\mathrm{T} 4$ & 0kg NPK/ha +2.5 tons $/$ ha PM & $22.57 \pm 096^{f}$ & $78.80 \pm 5.38^{\mathrm{abc}}$ & $241.00 \pm 2.65^{\mathrm{c}}$ \\
\hline T5 & 0kg NPK/ha + 5tons /ha PM & $25.27 \pm 1.21^{\text {cde }}$ & $84.47 \pm 14.60^{\mathrm{ab}}$ & $255.67 \pm 1.53^{b}$ \\
\hline T6 & 0kg NPK/ha + 10tons/ha PM & $29.20 \pm 1.56^{\mathrm{a}}$ & $95.27 \pm 4.63^{\mathrm{a}}$ & $270.67 \pm 6.81^{\mathrm{a}}$ \\
\hline $\mathrm{T} 7$ & $150 \mathrm{~kg} \mathrm{NPK} / \mathrm{ha}+2.5$ tons/ha PM & $27.83 \pm 0.75^{\mathrm{ab}}$ & $67.07 \pm 7.45^{\mathrm{cd}}$ & $220.33 \pm 1.53^{\mathrm{de}}$ \\
\hline $\mathrm{T} 8$ & $150 \mathrm{~kg} \mathrm{NPK} / \mathrm{ha}+5$ tons $/ \mathrm{ha}$ PM & $24.96 \pm 1.33^{\mathrm{de}}$ & $70.27 \pm 5.12^{\text {cd }}$ & $223.67 \pm 3.06^{\mathrm{d}}$ \\
\hline T9 & 150kg NPK/ha + 10tons/ha PM & $26.63 \pm 1.06^{\mathrm{bcd}}$ & $67.07 \pm 6.70^{\mathrm{cd}}$ & $200.00 \pm 10.82^{\mathrm{fg}}$ \\
\hline $\mathrm{T} 10$ & 180kg NPK/ha + 2.5tons/ha PM & $26.271 .40^{\mathrm{bcd}}$ & $65.53 \pm 5.80^{\mathrm{cd}}$ & $221.0 \pm 4.58^{\mathrm{de}}$ \\
\hline $\mathrm{T} 11$ & 180kg NPK/ha + 5tons/ha PM & $27.24 \pm 2.36^{\mathrm{abc}}$ & $76.9114 .91^{\mathrm{bcd}}$ & $190.67 \pm 5.13^{g}$ \\
\hline T12 & 180kg NPK/ha + 10tons/ha PM & $23.77 \pm 0.76^{\mathrm{ef}}$ & $64.00 \pm 7.53^{\mathrm{cd}}$ & $199.33 \pm 14.36^{\mathrm{fg}}$ \\
\hline
\end{tabular}

Means \pm standard deviations (SD) are shown. In a column, means with the same letters are not significantly different (Fisher's multiple range test 5\%). $\mathbf{P M =}$ Poultry manure

\subsection{Effects of Different Rates of NPK fertilizer and Poultry Manure on Number of Leaves}

The results shown in table 3 reveals that the number of leaves produced by plants increased from one growth stage to the other for all treatments. At $4 \mathrm{WAP}$, the number of leaves per plant in the control plot was the lowest and differed significantly $(\mathrm{P}<0.05)$ from those in the T6, T7, T10 and T11 treatments. At 8WAP and 12WAP, the number of leaves per plant in the T6 treatment was the highest and significantly differed from those of the other treatments. The control treatment significantly recorded the lowest number of leaves per plant at all the growth stages. 
International Journal of Advances in Scientific Research and Engineering (ijasre), Vol 5 (4), April-2019

Table 3: Effects of different rates of NPK fertilizer and Poultry manure on number of leaves per plant.

\begin{tabular}{|c|c|c|c|c|}
\hline \multirow{2}{*}{$\begin{array}{l}\text { Treatment } \\
\text { Code }\end{array}$} & \multirow[t]{2}{*}{ Treatment } & \multicolumn{3}{|c|}{ Weeks after planting } \\
\hline & & 4 & 8 & 12 \\
\hline TI & Control & $4.27 \pm 0.31^{\mathrm{d}}$ & $5.20 \pm 0.20^{\mathrm{e}}$ & $8.87 \pm 0.81^{\mathrm{e}}$ \\
\hline $\mathrm{T} 2$ & 300kg NPK/ha + 0kg PM/ha & $4.87 \pm 0.64^{\mathrm{bcd}}$ & $6.47 \pm 0.76^{\text {bcd }}$ & $11.20 \pm 0.60^{b}$ \\
\hline $\mathrm{T} 3$ & 150kg NPK/ha + 0kg PM/ha & $4.6 \pm 0.53^{\mathrm{bcd}}$ & $6.27 \pm 0.64^{\text {bcde }}$ & $11.23 \pm 0.40^{b}$ \\
\hline $\mathrm{T} 4$ & $0 \mathrm{~kg}$ NPK$/ \mathrm{ha}+2.5$ tons $/ \mathrm{ha} \mathrm{PM}$ & $4.73 \pm 0.42^{\text {bcd }}$ & $7.27 \pm 0.64^{b}$ & $11.33 \pm 0.31^{b}$ \\
\hline $\mathrm{T} 5$ & 0kg NPK/ha + 5tons /ha PM & $5.27 \pm 0.58^{\mathrm{bcd}}$ & $7.27 \pm 0.58^{b}$ & $11.27 \pm 0.12^{b}$ \\
\hline T6 & 0kg NPK/ha + 10tons/ha PM & $5.60 \pm 0.20^{\mathrm{a}}$ & $8.80 \pm 0.35^{\mathrm{a}}$ & $12.93 \pm 0.76^{\mathrm{a}}$ \\
\hline $\mathrm{T} 7$ & 150kg NPK/ha + 2.5tons/ha PM & $5.07 \pm 0.42^{\mathrm{abc}}$ & $6.271 .36^{\text {bcde }}$ & $10.80 \pm 0.53^{\mathrm{bc}}$ \\
\hline $\mathrm{T} 8$ & 150kg NPK/ha + 5tons/ha PM & $4.40 \pm 0.20^{\text {cd }}$ & $6.47 \pm 0.46^{\mathrm{bcd}}$ & $10.27 \pm 0.31^{\mathrm{cd}}$ \\
\hline T9 & 150kg NPK/ha + 10tons/ha PM & $4.47 \pm 0.23^{\mathrm{cd}}$ & $5.93 \pm 0.12^{\text {cde }}$ & $10.80 \pm 0.20^{\mathrm{bc}}$ \\
\hline T10 & 180kg NPK/ha + 2.5tons/ha PM & $5.07 \pm 0.61^{\mathrm{abc}}$ & $6.60 \pm 0.35^{\mathrm{bcd}}$ & $10.60 \pm 0.40^{\text {bcd }}$ \\
\hline T11 & 180kg NPK/ha + 5tons/ha PM & $4.8 \pm 0.20^{\mathrm{bcd}}$ & $6.93 \pm 0.76^{b c}$ & $10.00 \pm 0.20^{\mathrm{d}}$ \\
\hline T12 & 180kg NPK/ha + 10tons/ha PM & $5.27 \pm 0.31^{\mathrm{ab}}$ & $5.73 \pm 0.83^{\mathrm{de}}$ & $9.87 \pm 0.31^{\mathrm{d}}$ \\
\hline
\end{tabular}

Means \pm standard deviations (SD) are shown. In a column, means with the same letters are not significantly different (Fisher's multiple range test 5\%)

\subsection{Effect of Different Rates of NPK fertilizer and Poultry Manure on Stem Girth}

The data presented on table 4 show that the stem girth increased across the growth stages for all the treatments. For all the growth stages, the highest stem girth was seen in the T6 treatment. At 4WAP, the stem girth in the control plot was the lowest and differed significantly $(\mathrm{P}<0.05)$ from those in T6, T7, T8, T10, T11 and T12 treatments. At 8WAS and 12WAS, the stem girth in the T9 and T12 treatments were the lowest respectively and showed no significant difference $(\mathrm{P}>0.05)$ from that in the control plot.

Table 4: Effects of different rates of NPK and Poultry manure on Stem girth $(\mathrm{cm})$

\begin{tabular}{|c|c|c|c|c|}
\hline \multirow{2}{*}{$\begin{array}{l}\text { Treatment } \\
\text { Code }\end{array}$} & \multirow[t]{2}{*}{ Treatment } & \multicolumn{3}{|c|}{ Weeks after planting } \\
\hline & & 4 & 8 & 12 \\
\hline $\mathrm{T} 1$ & Control & $0.81 \pm 0.03^{\mathrm{d}}$ & $1.73 \pm 0.19^{\mathrm{cd}}$ & $2.00 \pm 0.06^{\text {bcde }}$ \\
\hline $\mathrm{T} 2$ & 300kg NPK/ha + 0kg PM/ha & $0.92 \pm 0.01^{\text {bcd }}$ & $1.80 \pm 0.25^{\mathrm{bcd}}$ & $2.07 \pm 0.09^{\mathrm{bc}}$ \\
\hline T3 & 150kg NPK/ha + 0kg PM/ha & $0.86 \pm 0.03^{\mathrm{cd}}$ & $1.95 \pm 0.40^{\mathrm{bcd}}$ & $2.15 \pm 0.19^{b}$ \\
\hline T4 & 0kg NPK/ha +2.5 tons $/$ ha PM & $0.89 \pm 0.04^{\mathrm{bcd}}$ & $2.05 \pm 0.14^{\mathrm{bc}}$ & $2.09 \pm 0.10^{\mathrm{bc}}$ \\
\hline T5 & 0kg NPK/ha + 5tons /ha PM & $0.89 \pm 0.15^{\mathrm{bcd}}$ & $2.14 \pm 0.20^{b}$ & $1.99 \pm 0.16^{\text {bcde }}$ \\
\hline T6 & 0kg NPK/ha + 10tons/ha PM & $1.06 \pm 0.06^{\mathrm{a}}$ & $2.64 \pm 0.12^{\mathrm{a}}$ & $2.74 \pm 0.13^{\mathrm{a}}$ \\
\hline $\mathrm{T} 7$ & 150kg NPK/ha + 2.5tons/ha PM & $0.99 \pm 0.03^{\mathrm{ab}}$ & $1.99 \pm 0.38^{\mathrm{bcd}}$ & $1.85 \pm 0.11^{\mathrm{de}}$ \\
\hline T8 & 150kg NPK/ha + 5tons $/$ ha PM & $0.92 \pm 0.05^{\mathrm{bc}}$ & $1.92 \pm 0.04^{\mathrm{bcd}}$ & $1.94 \pm 0.04^{\text {cde }}$ \\
\hline T9 & 150kg NPK/ha + 10tons/ha PM & $0.91 \pm 0.03^{\mathrm{bcd}}$ & $1.66 \pm 0.15^{\mathrm{d}}$ & $1.99 \pm 0.03^{\text {bcde }}$ \\
\hline T10 & 180kg NPK/ha + 2.5tons/ha PM & $0.93 \pm 0.04^{\mathrm{bc}}$ & $1.77 \pm 0.03^{\mathrm{cd}}$ & $2.03 \pm 0.04^{\mathrm{bcd}}$ \\
\hline T11 & 180kg NPK/ha + 5tons/ha PM & $0.92 \pm 0.07^{\mathrm{bc}}$ & $1.95 \pm 0.07^{\mathrm{bcd}}$ & $1.96 \pm 0.03^{\text {cde }}$ \\
\hline T12 & 180kg NPK/ha + 10tons/ha PM & $0.87 \pm 0.09^{\text {cd }}$ & $1.82 \pm 0.06^{\mathrm{bcd}}$ & $1.84 \pm 0.12^{\mathrm{e}}$ \\
\hline
\end{tabular}

Means \pm standard deviations (SD) are shown. In a column, means with the same letters are not significantly different (Fisher's multiple range test $5 \%$

3.4 Effect of Different Rates of NPK fertilizer and Poultry Manure on Ear Height and Leaf Area

3.4.1 Ear height: The information in Table 5 show that the lowest ear height $(119.67 \mathrm{~cm})$ was seen in the T11 and T12 treatments while the highest $(138.33 \mathrm{~cm})$ was recorded in the T6 treatment. Apart from T4 and T7, the ear height in the T6 plot differed significantly $(\mathrm{P}<0.05)$ from those in the rest of the treatments. 
3.4.2 Leaf area: The results in Table 5 reveal that the lowest leaf area $\left(397.81 \mathrm{~cm}^{2}\right)$ came from the control plot while the highest $\left(761.91 \mathrm{~cm}^{2}\right)$ was seen in the T6 plot. The leaf area in the T6 plot differed significantly $(\mathrm{P}<0.05)$ from those in the other treatments except the leaf area in the T7 plot which showed no significant difference $(\mathrm{P}>0.05)$ that in the T6 plot.

Table 5: Effects of different rates of NPK and Poultry manure on ear height and leaf area

\begin{tabular}{|c|c|c|c|}
\hline $\begin{array}{l}\text { Treatment } \\
\text { Code }\end{array}$ & Treatment & Ear height & Leaf area \\
\hline TI & Control & $133.35 \pm 18.93^{\mathrm{ab}}$ & $397.81 \pm 79.35^{\mathrm{d}}$ \\
\hline $\mathrm{T} 2$ & 300kg NPK/ha + 0kg PM/ha & $125.00 \pm 4.58^{\mathrm{bc}}$ & $559.17 \pm 39.86^{\mathrm{b}}$ \\
\hline T3 & 150kg NPK/ha + 0kg PM/ha & $128.67 \pm 5.77^{\mathrm{abc}}$ & $458.12 \pm 174.87^{\mathrm{bcd}}$ \\
\hline $\mathrm{T} 4$ & $0 \mathrm{~kg} \mathrm{NPK} / \mathrm{ha}+2.5$ tons $/ \mathrm{ha}$ PM & $128.67 \pm 3.79^{\mathrm{abc}}$ & $478.44 \pm 49.36^{\text {bcd }}$ \\
\hline T5 & 0kg NPK/ha + 5tons /ha PM & $125.67 \pm 8.96^{\mathrm{bc}}$ & $559.62 \pm 42.81^{\mathrm{b}}$ \\
\hline T6 & 0kg NPK/ha + 10tons/ha PM & $138.33 \pm 1.53^{\mathrm{a}}$ & $761.91 \pm 11.31^{\mathrm{a}}$ \\
\hline $\mathrm{T} 7$ & 150kg NPK/ha + 2.5tons/ha PM & $131.33 \pm 9.29^{\mathrm{abc}}$ & $485.82 \pm 2.96^{\mathrm{abc}}$ \\
\hline T8 & $150 \mathrm{~kg} \mathrm{NPK} / \mathrm{ha}+5$ tons $/ \mathrm{ha} \mathrm{PM}$ & $132.00 \pm 2.65^{\mathrm{abc}}$ & $567.06 \pm 105.28^{b}$ \\
\hline T9 & 150kg NPK/ha + 10tons/ha PM & $120.00 \pm 2.08^{c}$ & $476.98 \pm 23.64^{\text {bcd }}$ \\
\hline $\mathrm{T} 10$ & 180kg NPK/ha + 2.5tons/ha PM & $123.00 \pm 4.36^{\mathrm{bc}}$ & $501.06 \pm 22.18^{\mathrm{bcd}}$ \\
\hline T11 & 180kg NPK/ha + 5tons/ha PM & $119.67 \pm 3.06^{\mathrm{c}}$ & $540.42 \pm 55.14^{\text {bc }}$ \\
\hline T12 & 180kg NPK/ha + 10tons/ha PM & $119.67 \pm 3.06^{\mathrm{c}}$ & $432.78 \pm 68.78^{\mathrm{cd}}$ \\
\hline
\end{tabular}

Means \pm standard deviations (SD) are shown. In a column, means with the same letters are not significantly different (Fisher's multiple range test $5 \%$ )

\subsection{Effect of different rates of NPK and Poultry manure on Stem girth}

3.5.1 Ear length: The highest ear length was recorded in the $T 6$ treatment and was significantly different $(P<0.05)$ from those of other treatments (Table 6). This was closely followed by T5 with ear length which differed significantly from T2, T3, T4, T9, T10, T11 and T12 but did not differ significantly $(\mathrm{P}>0.05)$ from T8. The control treatment gave the lowest ear length and differed significantly from those of other treatments

3.5.2 Ear girth: The highest ear girth was seen in the T6 treatment and was significantly different $(\mathrm{P}<0.05)$ from the other treatments (Table 6). This was followed by T5 with ear girth which also differed significantly from those of the other treatments. The control treatment gave the lowest ear girth and differed significantly from those of other treatments.

3.5.3 Number of grain rows per ear: The highest number of grain rows per ear was recorded in the T6 treatment and was significantly different $(\mathrm{P}<0.05)$ from those of other treatments (Table 6). This was closely followed by T5 with number of grain rows per ear which also differed significantly from those of the other treatments. The control and T10 treatments gave the lowest number of grains per ear and differed significantly from those of other treatments.

3.5.4 Number of grains per ear: The highest number of grains per ear was recorded in the T6 treatment and showed no significant difference $(\mathrm{P}>0.05)$ from those of the T2, T4, T5, T7, T8 and T9 treatments (Table 6). The control plot recorded the lowest number of grains per ear and differed significantly from those of the rest of the treatments

3.5.5 Weight of 1000 grains: The highest weight of 1000 grains was registered in the T12 treatment and was significantly different $(\mathrm{P}<0.05)$ from those of other treatments (Table 6). This was closely followed by T6 with weight of 1000 grains which also differed significantly from those in the rest of the treatments. The control treatment gave the lowest weight of 1000 grains and differed significantly from those of other treatments.

3.5.6 Yield in tons per hectare: The highest yield was recorded in the T6 treatment and was significantly different $(\mathrm{P}<0.05)$ from those of other treatments (Table 6). This was closely followed by the yields in the T4 and T5 treatments which differed significantly from the yields in the T3, T4, T8, T9, T10, T11 and T12 treatments but did not differ significantly (P>0.05) from the yield of the $\mathrm{T} 2$ treatment. The control treatment gave the lowest yield and differed significantly from those of other treatments. 
International Journal of Advances in Scientific Research and Engineering (ijasre), Vol 5 (4), April-2019

Table 6: Effects of different rates of NPK and Poultry manure on maize yield and yield components

\begin{tabular}{|c|c|c|c|c|c|c|c|}
\hline $\begin{array}{l}\text { Treatment } \\
\text { Code }\end{array}$ & Treatment & $\begin{array}{l}\text { Ear } \\
\text { length }(\mathrm{cm})\end{array}$ & $\begin{array}{ll}\text { Ear } & \text { girth } \\
(\mathbf{c m}) & \end{array}$ & $\begin{array}{l}\text { No of grain } \\
\text { rows/ear }\end{array}$ & $\begin{array}{l}\text { No of grains } \\
\text { per ear }\end{array}$ & $\begin{array}{l}\text { 1000grain } \\
\text { weight(g) }\end{array}$ & $\begin{array}{l}\text { Yield } \\
\text { ton/ha }\end{array}$ \\
\hline $\mathrm{T} 1$ & Control & $11.84 \pm 0.83^{\mathrm{h}}$ & $11.48 \pm 0.44^{\mathrm{e}}$ & $10.60 \pm 0.20^{\mathrm{h}}$ & $287.33 \pm 20.4^{\mathrm{d}}$ & $226.33 \pm 9.29^{c}$ & $3.25 \pm 0.39^{\mathrm{e}}$ \\
\hline $\mathrm{T} 2$ & $\begin{array}{l}\text { 300kg NPK/ha + } \\
0 \mathrm{~kg} \mathrm{PM} / \mathrm{ha}\end{array}$ & $17.75 \pm 0.61^{\mathrm{c}}$ & $15.22 \pm 0.36^{\mathrm{c}}$ & $14.53 \pm 0.31^{\mathrm{ab}}$ & $524.33 \pm 36.50^{\mathrm{a}}$ & $233.00 \pm 6.08^{\mathrm{bc}}$ & $6.02 \pm 0.42^{\mathrm{b}}$ \\
\hline T3 & $\begin{array}{l}150 \mathrm{~kg} \mathrm{NPK} / \mathrm{ha}+ \\
0 \mathrm{~kg} \mathrm{PM} / \mathrm{ha}\end{array}$ & $16.76 \pm 0.51^{\text {def }}$ & $14.30 \pm 0.56^{\mathrm{c}}$ & $12.47 \pm 0.12^{\text {cde }}$ & $478.00 \pm 82.50^{\mathrm{ab}}$ & $237.67 \pm 4.04^{\mathrm{bc}}$ & $5.27 \pm 0.21^{\mathrm{c}}$ \\
\hline $\mathrm{T} 4$ & $\begin{array}{l}0 \mathrm{~kg} \mathrm{NPK} / \mathrm{ha}+ \\
2.5 \text { tons } / \mathrm{ha} \mathrm{PM}\end{array}$ & $17.37 \pm 0.21^{\text {cde }}$ & $15.12 \pm 1.66^{\mathrm{c}}$ & $11.50 \pm 0.89^{\mathrm{fg}}$ & $535.67 \pm 32.72^{\mathrm{a}}$ & $240.00 \pm 7.94^{\mathrm{bc}}$ & $6.23 \pm 0.06^{\mathrm{b}}$ \\
\hline T5 & $\begin{array}{l}\text { 0kg NPK/ha }+ \\
\text { 5tons /ha PM }\end{array}$ & $19.06 \pm 0.20^{\mathrm{b}}$ & $16.81 \pm 0.50^{\mathrm{b}}$ & $13.93 \pm 0.12^{\mathrm{b}}$ & $519.67 \pm 44.41^{\mathrm{a}}$ & $246.00 \pm 10.58^{\mathrm{abc}}$ & $6.23 \pm 0.12^{\mathrm{b}}$ \\
\hline T6 & $\begin{array}{l}\text { 0kg NPK/ha }+ \\
\text { 10tons/ha PM }\end{array}$ & $20.27 \pm 0.16^{\mathrm{a}}$ & $17.97 \pm 0.18^{\mathrm{a}}$ & $14.93 \pm 0.23^{\mathrm{a}}$ & $550.00 \pm 26.15^{\mathrm{a}}$ & $261.33 \pm 1.53^{\mathrm{ab}}$ & $7.09 \pm 0.02^{\mathrm{a}}$ \\
\hline $\mathrm{T} 7$ & $\begin{array}{l}\text { 150kg NPK/ha }+ \\
2.5 \text { tons/ha PM }\end{array}$ & $17.59 \pm 0.54^{\mathrm{cd}}$ & $14.99 \pm 0.03^{\mathrm{c}}$ & $12.53 \pm 0.31^{\mathrm{cd}}$ & $490.33 \pm 21.03^{\mathrm{a}}$ & $242.67 \pm 9.29^{\mathrm{abc}}$ & $5.25 \pm 0.05^{\mathrm{c}}$ \\
\hline T8 & $\begin{array}{l}\text { 150kg NPK/ha + } \\
\text { 5tons/ha PM }\end{array}$ & $18.93 \pm 0.56^{\mathrm{b}}$ & $14.55 \pm 0.38^{\mathrm{c}}$ & $12.93 \pm 0.23^{\mathrm{c}}$ & $531.67 \pm 41.10^{\mathrm{a}}$ & $246.00 \pm 6.08^{\mathrm{abc}}$ & $5.15 \pm 0.12^{\mathrm{c}}$ \\
\hline T9 & $\begin{array}{l}\text { 150kg NPK/ha + } \\
\text { 10tons/ha PM }\end{array}$ & $15.95 \pm 0.81^{\mathrm{f}}$ & $13.26 \pm 0.09^{d}$ & $11.90 \pm 0.26^{\mathrm{ef}}$ & $517.33 \pm 46.07^{\mathrm{a}}$ & $246.00 \pm 4.58^{\mathrm{abc}}$ & $5.41 \pm 0.38^{\mathrm{c}}$ \\
\hline $\mathrm{T} 10$ & $\begin{array}{l}180 \mathrm{~kg} \mathrm{NPK} / \mathrm{ha}+ \\
2.5 \text { tons } / \mathrm{ha} \mathrm{PM}\end{array}$ & $14.78 \pm 0.67^{\mathrm{g}}$ & $12.98 \pm 0.23^{\mathrm{d}}$ & $10.60 \pm 0.20^{\mathrm{h}}$ & $406.67 \pm 62.66^{\mathrm{bc}}$ & $232.67 \pm 2.31^{\mathrm{bc}}$ & $4.420 .13^{\mathrm{d}}$ \\
\hline T11 & $\begin{array}{l}180 \mathrm{~kg} \mathrm{NPK} / \mathrm{ha}+ \\
5 \text { tons/ha PM }\end{array}$ & $16.60 \pm 0.12^{\mathrm{ef}}$ & $14.29 \pm 0.46^{\mathrm{c}}$ & $11.93 \pm 0.50^{\text {def }}$ & $480.33 \pm 72.82^{\mathrm{ab}}$ & $236.33 \pm 1.15^{\mathrm{bc}}$ & $4.17 \pm 0.08^{\mathrm{d}}$ \\
\hline $\mathrm{T} 12$ & $\begin{array}{l}\text { 180kg NPK/ha }+ \\
\text { 10tons/ha PM }\end{array}$ & $15.94 \pm 0.23^{f}$ & $13.12 \pm 0.27^{\mathrm{d}}$ & $11.20 \pm 0.20^{\text {gh }}$ & $381.00 \pm 16.70^{c}$ & $272.33 \pm 59.47^{\mathrm{a}}$ & $4.12 \pm 0.06^{\mathrm{d}}$ \\
\hline
\end{tabular}

Means \pm standard deviations (SD) are shown. In a column, means with the same letters are not significantly different (Fisher's multiple range test $5 \%$ )

\section{DISCUSSION}

The results from this study reveal that the different application rates of NPK fertilizer and poultry manure significantly improved maize growth and yield. Higher yields were achieved with the application rates of $0 \mathrm{Kg} \mathrm{NPK} / \mathrm{ha}+10$ tons PM/ha (T6), 0Kg NPK/ha + 5tons PM/ha (T5), 300Kg NPK/ha + 0Kg PM/ha (T2) and 0Kg NPK/ha + 2.5tons PM/ha (T4). This was proven in the plant height and the number of leaves produced per plant. The highest number of leaves was achieved with the application rate of $0 \mathrm{Kg}$ NPK/ha +10 tons PM/ha (T6). This can be attributed to the fact that poultry manure enhanced vegetative growth in maize ${ }^{[8]}$.

The leaf area was greatly influence by the rates of NPK fertilizer and poultry manure application. There was an increase in the leaf area with increased rates of poultry manure and NPK fertilizer applications. This is in line with past works that reveal that higher rates of poultry manure ${ }^{[8]}$ and nitrogenous fertilizer [maize fertilizer rate] promote leaf area during vegetative growth.

The application rates of $0 \mathrm{Kg}$ NPK/ha + 10tons PM/ha (T6) significantly improved grain yield. The ear length, ear girth, number of grain rows per ear, number of grains per ear, and weight of 1000 grains were maximum with this application rate. This is in accordance with previous findings which reveal that higher poultry manure application rates enhanced yield and yield components in maize ${ }^{[1]}$. The fertilizer rate of $300 \mathrm{Kg}$ NPK/ha $+0 \mathrm{Kg}$ PM/ha (T2) also gave higher yield as compared to the other NPK doses. This confirms results from earlier works which demonstrate that higher nitrogen and phosphorus fertilizer application rates improved maize yield [maize fertilizer rate]. Yield reductions were noted with the application rates of $180 \mathrm{Kg}$ NPK/ha +2.5 tons PM/ha (T10), $180 \mathrm{Kg} \mathrm{NPK/ha} \mathrm{+} \mathrm{5tons} \mathrm{PM/ha} \mathrm{(T11)} \mathrm{and} 180 \mathrm{Kg} \mathrm{NPK/ha} \mathrm{+} \mathrm{10tons} \mathrm{PM/ha} \mathrm{(T12).} \mathrm{This} \mathrm{may} \mathrm{be} \mathrm{attributed} \mathrm{to} \mathrm{nutrient}$ imbalance. Similar reports have been given where higher phosphorus rates caused nutrient imbalance in combination with nitrogenous fertilizer ${ }^{[9],[10]}$. All NPK fertilizer and poultry manure rates significantly increased maize yields over the control plots. This emphasizes the necessity of amending poor soils towards greater crop yields, confirming results from previous studies which reveal that all fertilizer application plots gave higher yields than the non-fertilizer applied plots (control) ${ }^{[11]}$.

\section{CONCLUSION}

The findings from this study reveal that the different application rates of NPK fertilizer and poultry manure significantly improved maize growth and yield. Higher yields were achieved with the application rates of $0 \mathrm{Kg} \mathrm{NPK} / \mathrm{ha}+10$ tons PM/ha (T6), 0Kg NPK/ha + 5tons PM/ha (T5), 300Kg NPK/ha + 0Kg PM/ha (T2) and 0Kg NPK/ha + 2.5tons PM/ha (T4). The treatment $150 \mathrm{KgNPK} / \mathrm{ha}+2.5$ tons PM/ha also achieved higher yields and may be recommended for maize producers in the study area since it is economical in terms of cost of production. This study clearly indicates that poultry manure is a vital fertilizer whose use needs to be encourage to the local farmers. 


\section{REFERENCES}

[1] Foncha, F., Bame, I. B., Lendzemo,V. W., Nsuh, K.C., Etta, C., Mbong, G.A., Nchinda, V.P., Mafouasson, O. H., Christopher, S. and Noe, W. (2019). Growth and Yield Response of Maize to Different Weed Control Methods in the Western Highlands of Cameroon. Journal of Agriculture and Crops, 5(2): 15-22.

[2] Ranum, P., Juan, P.P-R. and Maria, N.G-C. (2014). Global maize production, utilization, and consumption. Ann. N.Y. Acad.Sci. Vol. 13(12):105-112.

[3] Cairns, J.E., Jose, C.P.H., Zaidi, P.G., Ciro, S., Jose, L.A., Suriphat, T.D.M., Sarah, H. and Gary, N.A. (2013). Identification of Drought, Heat, and Combined Drought and Heat Tolerant Donors in Maize. CROP SCIENCE, Vol.53: 13351345 .

[4] Sibiya, J., Pangirayi, T.J.D. and Itai, M. (2013). Small holder farmers' perceptions of maize diseases, pests and other constraints, their implications in maize breeding and evaluation of local cultivars in South Africa:

KwaZu;lu Natal.

[5] MINEPAT, (2008). Rapport d'etude sur le fillier Mais. pp. 110.

[6] DT MAIZE, (2012). A Quarterly Bulletin of the Drought Tolerant Maize for Africa Project. Vol. 1 No.1; 4pp.

[7] Saxena, M.C. and Y.Singh, (1965). A note on leaf area estimation of intact leaves. Indian J. Agron, 10:437-439.

[8] Agyenim, S.B., Zickermann, J. and Kornahrens (2006). Poultry Manure Effect on Growth and Yield of Maize. West African Journal of Applied Ecology (WAJAE), Vol 9, ISSN: 0855-4307.

[9] Onasanya, R.O., Aiyelari. O.P., Onasanya, A., Oikeh, S., Nwilene, F.E. and Oyelakin, O.O. (2009). Growth and Yield Response of Maize (Zea mays L.) to Different Rates of Nitrogen and Phosphorus fertilizers in Southern Nigeria. World Journal of Agricultural Sciences, 5(4): 400-407.

[10] Adeptu, J.A. (1970). The relative importance of phosphorus to crop nutrition in soils of Western Nigeria. M.Phil. Thesis, University of Ife, Ile-Ife, Nigeria. pp: 1-75.

[11] Ekesiobi, I.A., Ndukwe, O.O., Ezeono, C.A., Odukwe, R.A. and Nnabuife E.L.C. (2015). Influence of Complementary Rates of Poultry Manure and Urea Fertilizers on Growth and Yield of Maize (Zea mays L. Walp) in South-eastern Agroecology. International Journal of Applied Sciences and Engineering, 3(1): 8-13. 